їх, робити мотивовані висновки й подавати необхідні практичні рекомендації з урахуванням опанованих основ дискурсології.

Засвоєні магістрантами-філологами окремі положення методології дискурсу дійсно сприяють формуванню їхньої дослідницької компетентності, насамперед удосконаленню вмінь використовувати ефективні методи дослідження, зіставляти наукові явища, усвідомлюючи мову як джерело й одночасно як засіб дослідницької діяльності.

Порушена проблема в цій публікації тільки окреслює перспективи подальших досліджень. Так, потребує сучасного теоретичного обгрунтування зміст вивчення дискурсології в окремому навчальному курсі для магістрантів-філологів чи в межах лінгвістичних і лінгводидактичних дисциплін, на часі вдосконалення лінгводидактичних методів, прийомів і засобів, які інтегрують навчальну й наукову діяльність і спрямовані на формування дослідницької компетентності магістрантів-філологів.

\title{
Література
}

1 . Бацевич Ф. С. Основи комунікативної лінгвістики : [підручник] / Флорій Сергійович Бацевич. - Київ : Вид. центр «Академія», 2004. - 344 с. 2. Дискурс як когнітивно-комунікативний феномен : [монографія] / Л. Р. Безугла, Є. В. Бондаренко, П. М. Донець та ін. ; під заг. ред. І. С. Шевченко. - Харків : Константа, 2005. - 356 с. 3. Загальноєвропейські Рекомендації з мовної освіти: вивчення, викладання, оцінювання / наук. ред. укр. вид. С. Ю. Ніколаєва. - Київ : Ленвіт, 2003. - 273 с. 4. Педагогіка вищої школи : [навч. посіб.] / 3. Н. Курлянд, Р. І. Хмелюк, А. В. Семенова та ін. ; за ред. 3. Н. Курлянд. - [2-ге вид., переробл. і доп.]. - Київ : Знання, 2005. - 399 с. 5. Серажим К. Дискурс як соціолінгвальне явище: методологія, архітектоніка, варіативність (на матеріалах сучасної газетної публіцистики) : [монографія] / Катерина Серажим ; за ред. В. Різуна ; Київ. нац. ун-т ім. Тараса Шевченка. - Київ : Київ. нац. ун-т імені Тараса Шевченка, 2002. - 392 с. 6. Словник-довідник з української лінгводидактики : [навч. посіб.] / за ред. М. Пентилюк. Київ : Ленвіт, 2015. - 320 с. 7. Химинець В. В. Інноваційна освітня діяльність / В. В. Химинець. - Ужгород : ЗІППО, 2007. - 364 с.

\section{ПРОБЛЕМИ ВИКЛАДАННЯ ФІЗИЧНОГО ВИХОВАННЯ В КОНТЕКСТІ РОЗВИТКУ САМОРЕГУЛЯЦІї В УЧНІВ І СТУДЕНТІВ}

Переверзєва С. В. Проблеми викладання фізичного виховання в контексті розвитку саморегуляції в учнів і студентів

У статті обгрунтовано цільовий напрям розвитку фізичного виховання орієнтованого на педагогічний процес, який полягає у втіленні ефективних ідей, форм навчального змісту діяльності викладача у пріоритеті особистісно рорієнтованого виховання учнів і студентів. Аналізується система навчальної діяльності із застосуванням концептуальних положень і принципів.

Ключові слова: фізичне виховання, учень, студент, педагогічний процес, особистісно орієнтоване виховання, групова діяльність, гуманізація, інтелектуалізація, оптимізація, саморегуляція.

Переверзева С. В Проблемы преподавания физического воспитания в контексте развития саморегуляции у учеников и студентов. 
В статье обосновывается целенаправленное развития физического воспитания ориентированное на педагогический процесс, который состоит в осуществлении эффективных идей, форм содержания образовательной деятельности учителя в приоритете личностно ориентированное образование учащихся и студентов. Анализ системы образовательной деятельности с применением концептуальных положений и принципов.

Ключевые слова: физическое воспитание, ученик, студент, педагогический процесс обучения, личностно ориентированное воспитание, деятельность группы, гуманизация, интеллектуализация, оптимизация, саморегуляция.

Pereverzeva S. V. The problems of Physical Education training: selfregulation development of pupils and students.

In the article the intentional development of Physical Education focused on pedagogical process, which consists of implenetation of effective ideas, forms of teacher' educational activities using person centered training of pupils and students was grouned. The educational activity system with application of conceptual provisions and principles was analysed.

Key words: physical education, a pupil, a student, teaching process, person centered training, group activities, humanization, intellectualization, optimization, self-regulation.

Система фізичного виховання учнів і студентів спрямована нині лише на розв’язання проблем сьогоднішнього дня - здачу контрольних нормативів та залікових нормативів, що не сприяє виробленню в них прагнення до самостійного вдосконалення, націлює на виховання слухняного виконавця, орієнтованого на дотримання вимог програми з фізичного виховання. За таких умов - фізичної культури особистості не можна сформувати. Для цього необхідно змінити цільові установки сфери фізичної культури з концепції оздоровлення та фізичного виховання на формування фізичної культури особистості [3, с. 21].

Розвиток фізичного виховання, фізичної культури $\epsilon$ економічно вигідним i найефективнішим способом профілактики захворюваності та розв'язання низки соціальних проблем. Нині соціальне становлення суспільства базується і зорієнтоване на підготовку всебічно i гармонійно розвинутої особистості, яка в майбутньому буде висококваліфікованим спеціалістом обраної галузі, і реалізує себе в умовах жорсткої конкуренції. Так, у наукових працях А. Драчука, С. Канішевського, Р. Раєвського, О. Куца, наголошується на тому, що нинішня організація фізичного виховання $є$ недостатньо ефективною для підвищення рівня здоров’я, фізичної підготовленості та мотивації до систематичних занять фізичними вправами [3; 6; 7].

Але, на жаль, рівень фізичної підготовленості і здоров'я молоді щороку знижується і лишає бажати кращого. На думку дослідників Л. Рогалева, А. Царик, Т. Круцевич [4; 10], розв'язання цієї проблеми є можливим за умови дослідження мотивів та інтересів учнів та студентів стосовно занять фізичними вправами, виявлення причин, які перешкоджають займатися фізкультурною діяльністю, систематичного пояснення наслідків недостатньої рухової діяльності та ведення пропаганди здорового способу життя. Фізичне виховання і розвиток особистості вимагають особливої уваги з боку усіх життєво важливих виховних інститутів - сім’ї, школи, громадських організацій, навичок організації режиму повсякденної рухової активності.

Мета дослідження: проаналізувати форми організації фізичного виховання учнів і студентів за допомогою спеціально організованих концептуальних положень і принципів педагогічної системи. 
На сьогодні система фізичного виховання базується на принципі так званого соціального обов'язку, а не природного бажання. Відомо, що будь-якій людині властиво опиратися примусу. Тому «командно-стройовими» методами, які домінують на заняттях із фізичного виховання, практично не можливо домогтися ефекту у справі формування внутрішнього переконання потреби у фізичному вдосконаленні. Недооцінка цієї закономірності є однією з причин поступового виключення фізичного самовдосконалення зі сфери інтересів молодого покоління, зниження освітнього та виховного значення фізичного виховання [9, с. 12]. Перехід від першого до другого можливий за наявністю вибору школярем чи студентом виду рухової діяльності і форми проведення занять. Для реалізації вказаної можливості, як уважає А. Царик [10, с. 81], необхідна децентралізація навчальних програм із фізичного виховання, плюралізм форм проведення занять. Як приклад, можна навести коледжі та університети країн західної Європи та США. В них навчальна програма 3 фізичного виховання формується i розробляється 3 урахуванням інтересів i бажань студентської молоді. Студент має право сам обирати види рухової діяльності та форми проведення занять. Можливість вільного вибору $є$ важливим складником фізичного виховання, а також вагомим стимулом для відвідування учнями і студентами занять 3 фізичної культури і спортивних тренувань, стимулом, який формує потреби фізичного вдосконалення у навчальний та позанавчальний час і сприяє систематичності занять протягом життя.

У сучасній системі фізичного виховання в Україні особистість як індивід здебільшого ігнорується. Справа в тому, що увага переважно зосереджується на фізичному розвитку якостей, навичок та вмінь. Грубо кажучи, проводиться політика «зрівнялівки» - нормативи $€$ загально усталеними, не розробленими індивідуально, під особливості розвитку кожного окремого учня і студента. Це стало причиною того, що заняття з фізичного виховання в уявленні школярів і студентів стали позбавленими творчості, механізованими - «що наказують, те і робимо». Тобто відсутність вибору фізичної діяльності щодо особистості. Як наслідок для тих, хто займається, і має недостатній рівень фізичної підготовки - заняття перетворюються на непосильну роботу, що не сприяє отриманню задоволення і породжує комплекс неповноцінності. Створюється ситуація, за якої ані фізично сильні, ані слабкі учні і студенти не можуть адекватно оцінювати власні можливості та здібності. Як наслідок, перевага тілесного компонента в змісті фізичного виховання над соціокультурним деформує цінності фізичної культури, фізичне виховання втрачає риси гуманістичної спрямованості педагогічного процесу, його загальнокультурного та морального змісту. Сучасний педагогічний процес повинен утворювати стратегію, яка складається 3 суб'єктивного розвитку та саморозвитку особистості вчителя, здатного до продуктивно-перетворювальної діяльності на основі нових ідей, підходів, технологій.

Принципова спрямованість даної стратегії полягає у втіленні форм та змісту навчального процесу педагогічної діяльності на пріоритет особистісно-орієнтованих технологій педагогічної освіти. I. Бех [1, с. 37] стверджує: «Лише особистісно зорієнтованому вихованню під силу досягнення особистісно-розвивальної мети, оскільки воно спрямоване на усвідомлення вихованцем себе як особистості, на його вільне i відповідальне самовираження (свідомість, емоції, воля)». Аналіз літературних джерел вказує, на те що шкільні роки й навчальні взаємозв'язки посідають провідне місце в підготовці до майбутнього життя учнів, виконання ними різноманітних функцій у різних видах діяльності: навчанні, праці, відпочинку, спілкуванні, побуті. I в цьому напрямку педагогічний процес будується на основі суб’єкт-об’єктивних відносин, тому є підставою для усвідомлення й 
розвитку гуманістичних і демократичних ідей сьогодення.

На думку професора Б. Шияна, гуманізація процесу фізичного виховання виявляється у зміні форм спілкування, відмові від насильницьких методів у стосунках з молодим поколінням; створенні умов для усвідомленої участі в навчальному процесі його учасників; повній відповідності завдань, засобів і методів можливостям тих, хто займається, їх досвіду, рівню досягнень й інтересів; створенні умов кожному учаснику педагогічного процесу для повного розвитку своїх фізичних і духовних здібностей; перенацілені індивіда з результатів навчання на спроби їх досягнення [4, с. 23]. Тож викладач не стільки вчить і виховує, скільки актуалізує, стимулює молодь до загального і професійного розвитку. Особистісно зорієнтований розвиток реалізується в певній технічній послідовності: від максимальної допомоги викладача (учням, студентам) у розв’язанні навчальних завдань до поступового зростання їхньої власної активності, до повної саморегуляції у навчанні і вияву стосунків партнерства між (учнем, студентом) та викладачем [5, с. 101].

Фізичне виховання, як загальновизнаний засіб розвитку та підтримки фізичного та психічного здоров'я, водночас може слугувати як одна із найбільш зручних форм розвитку психічної саморегуляції учнів та студентів. Беручи за основу різноманітні аспекти людського існування, дослідники виокремлюють різні рівні саморегуляції: індивідуальний та особистісний; свідомий і несвідомий; операційно-технічний - основами цього рівня є образи розумових і моторних дій. Щодо мотиваційного рівня саморегуляції, то основами їі вважають ціннісно-смислові утворення.

Виокремлюють такі структурні компоненти саморегуляції:

- мета довільної активності, що прийнята суб’єктом;

- модель важливих умов діяльності;

- програма власних дій;

- система критеріїв успішної діяльності;

- інформація про реально досягнуті результати;

- оцінка відповідності результатів критеріям успіху;

- рішення про необхідність та характер корекції діяльності [8, с. 584].

Якщо правильно сформувати мотиваційний рівень саморегуляції учня або студента, то відбувається усвідомлення мети діяльності і її результатів шляхом саморегуляції власної поведінки за рахунок внутрішніх мотивів самовдосконалення. Що надалі $є$ орієнтацією особистості на належні норми і прогрес власних досягнень та зовнішніх стимулів створених викладачем.

Відомо, що раціонально організований процес формування об’єктивно усвідомленого інтересу (учнів, студентів) у навчально-виховній діяльності має серйозний вплив на стан здоров’я індивіда, до того ж сприяє реалізації його потенційного досвіду з подальшим використанням засобів фізичної культури у власному повсякденному житті 3 дотриманням здорового способу життя.

Навчання як процес цілеспрямованого передання і засвоєння визначеного досвіду можна здійснювати за допомогою різних форм і методів. Сутність такого здійснення визначається відповідно формою навчання. Систему форм навчальної діяльності на занятті становлять індивідуальна фронтальна та групова.

Так заняття, в яких перевага надається фронтальній та індивідуальній роботі, показують що (учні, студенти), малоактивні в обговоренні пропонованих питань, уникають публічних виступів, під час опитування викладачем відчувають значний психологічний 
дискомфорт. Але варто звернути увагу на індивідуальний підхід викладача під час роботи з медичними групами. Адже незважаючи на те, що розподіл за рівнем здоров'я, фізичного розвитку, фізичної і спортивної підготовленості поділяють на чотири групи (основна, підготовча, спеціальна та звільненні), та всередині самих груп є більш і менш підготовлені (учні, студенти), тобто групи за своїм складом не є рівними. Саме тому потрібний більш індивідуалізований підхід до кожного під час занять, а також при наданні домашнього завдання. Груповою формою навчальної діяльності (учнів, студентів) називають організовану викладачем роботу невеликої групи або мікрогрупи (можливо за медичними групами, тож це поєднання індивідуальної і групової форми роботи) над спільним навчальним завданням. Задля забезпечення ефективності, творчості і щільності занять доцільно застосовувати групову форму діяльності, що загалом компенсує недоліки фронтальної та індивідуальної роботи.

Групова робота будується на взаємному обговоренні теоретичного і виправленні та складанні практичного завдання у групах, тому сприяє більш глибокому розумінню i засвоєнню навиків, техніки та термінології з фізичного виховання. Такий напрямок роботи набуває характеру співпраці вихованців з викладачем. Викладач не втручається у роботу групи, тільки в тому разі, якщо виникає у (учнів, студентів) запитання чи розбіжності у думках, і вони самі звертаються по допомогу до викладача. Групова навчальна діяльність, на відміну від фронтальної та індивідуальної, не ізолює студентів один від одного, а навпаки, дозволяє реалізувати природне прагнення до спілкування, взаємодопомоги і співпраці, сприяє встановленню доброзичливих стосунків між (учнями, студентами) Ідеї, висунуті та усвідомлені одним студентом, підхоплюються, обговорюються, доповнюються іншими, стають надбанням усієї мікрогрупи. Таким способом формується пізнавальна активність, самостійність, атмосфера психологічного комфорту особистості [4, с. 406].

Зрозуміло, що групова навчальна діяльність (учнів, студентів) не протиставляється іншим формам, у тому числі традиційним, і повинна оптимально поєднуватися з ними.

Водночас успіхи студентів, виражені також в оцінці, і відбивають якість педагогічної праці, результат діяльності викладача, його уміння висувати завдання, опановувати відповідні засоби і методи організації фізичного виховання. Б. Леко вказує, що досить часто проведення занять зводиться до звичайного складання нормативів, до того ж це робиться примусово [5, с. 93]. Така ситуація сприяє негативному налаштуванню учнів і студентів на самі нормативні вимоги і заняття 3 фізичного виховання. Варто оцінювати не стільки результати тестів, скільки їх зміну, адже саме зміна в той чи той бік показує, наскільки прогресивною (чи регресивною) $є$ взаємодія команди «викладач - учень або студент». Важливо, щоб у молоді не було страху перед оцінкою, що йде в журнал. Адже про яке заняття може йтися, якщо основною метою індивіда $є$ відбути заняття і не отримати негативної оцінки.

Для розв'язання вищезгаданих проблем фізичного виховання необхідно: подолати педагогічний авторитаризм у системі фізичного виховання; усунути зростаюче відчуження фізичного виховання від громадського життя, розвитку особистості та культури, збудувати нові стосунки між викладачем і тим, хто займається, на основі співдружності та довіри. На думку фахівців, ефективність процесу фізичного виховання значно зросте у разі більш широкого застосування таких основних концептуальних положень і принципів педагогічної системи, як: гуманізація, інтелектуалізація та оптимізація.

Активізація інтелектуальної системи і ї̈ висока ефективність убачає використання фізкультурно-оздоровчої роботи у навчальних та позанавчальних формах занять (лекційні, 
методичні, практичні, семінарські, секційні, спортивно-масові заходи, консультації), їх сукупність та використання методичних прийомів $є$ інформаційним забезпеченням і складає педагогічні умови для розвитку і реалізації власних психофізіологічних можливостей.

Важливе значення в оптимізації навчального процесу 3 фізичного виховання у навчальних закладах $є$ проведення системної роботи, що допоможе встановити проблеми і можливі шляхи їх усунення. Так, основна проблема постає у підвищенні рівня фізичної підготовки учнів та студентів, оптимізації їх психофізичного стану і поліпшення здоров’я. Тому необхідно визначити низку досліджень, і це забезпечить напрацювання і застосування навчально-методичного матеріалу в подальшій роботі викладача. Орієнтовні напрями досліджень: визначити рівень теоретичних знань; провести самооцінку здоров’я; з'ясувати рівень попередньої спортивної і методичної підготовки; діагностувати статус фізичного виховання в навчальному закладі; вивчити уявлення (учнів, студентів) про процес і напрямки розвитку фізичної культури; сформувати мотивацію до занять фізичною культурою.

Упровадження вищезгаданих концептуальних положень і принципів педагогічної системи, на думку академіка В. Андрущенко [2, с. 128], можливе за умови реформування системи вищої освіти відповідно до вимог Болонського процесу. Як зазначає I. Бех [1, с. 24], реалізація Болонського процесу в Україні в ідеалі покликана сприяти переходу від колективного до особистісно-орієнтованого процесу, який базується на гуманістичних напрямах філософії, психології та педагогіки і передбачає сприйняття кожного студента як унікальної особистості.

На основі вище викладеної інформації ми прийшли до висновку, що в Україні сучасна система викладання фізичного виховання має суттєві недоліки. Головними недоліками є недостатнє впровадження в навчальний процес принципів індивідуалізації, демократизації та гуманізації. Варто переглянути і доповнити модель фізичного виховання, в якій викладач має орієнтуватися не на програму, а на молоде покоління, захищаючи їх загальнолюдські, природні, біологічні та інші права. Саме тому розглянуте виховання гуманних стосунків передбачає запровадження в педагогічному процесі цілісної гуманної моделі виховання, в основі якої має бути особистісно зорієнтований розвиток учнів і студентів. Гуманізація й демократизація стосунків в навчально-виховному процесі базується на створенні інтелектуального напрямку оптимальних умов для розвитку молодого покоління, виявлення глибокої поваги до людини, визначення природного права особистості на свободу, соціальний захист, розвиток здібностей і вияв індивідуальності, самореалізацію фізичного та соціального потенціалу.

Перспективами для подальших досліджень встановлено у визначенні технологій удосконалення системи фізичного виховання учнів і студентів з різних видів фізкультурнооздоровчої діяльності на підгрунті особистісно зорієнтованого підходу.

\section{Література}

1. Бех И. Психологические основы нравственного развития личности : дисс. на соискание ученой степени доктора псих. наук : 19.00.07 / Бех Иван Дмитриевич. - Киев, 1992. - 320 с. 2. Бех В. П. Болонський процес : тенденції, проблеми, перспективи / В. П. Бех, Ю. Л. Маліновський. - Київ : НПУ імені М. П. Драгоманова, 2004. - 221 с. З. Зайцев Г. К. Потребностно-мотивационная сфера физического воспитания студентов / Г. К. Зайцев // Теория и практика физической культуры. - 1997. - № 7. - С. 21-24. 4. Ковальчук Г. Я. Використання особистісно орієнтованих технологій навчання на заняттях з біохімії як засіб підвищення якості підготовки фахівців з фізичного виховання та фізичної реабілітації / Г. Я. Ковальчук // Реалізація здорового способу життя - сучасні підходи / за заг.ред. 
М. Лук'янченка, Ю. Шкребтія, Е. Боляха, А. Матвєєва. - Дрогобич : КОЛО, 2005. - 624 с. 5. Леко Б. Державні тести з фізичної підготовленості : у чому суть проблеми? / Богдан Леко // Педагогіка, психологія та медико-біологічні проблеми фізичного виховання і спорту : [зб. наук. пр. за ред. С. С. Єрмакова]. - Харків : ХХПІ, 2003. - № 17. - С. 91-101. 6. Нісімчук А. С. Сучасні педагогічні технології/ А. С. Нісімчук, О. С. Падалка, О. Т. Шпак. - Київ : Просвіта, 2000. - 368с. 7. Освітні технології: [навч.-метод. посіб.] / за заг. ред. О. М. Пєхоти. - Київ : А.С.К., 2002. - 255 с. 8. Словарь практического психолога / сост. С. Ю. Головин. - Минск : Харвест, 1998. - 800 с. 9. Теория и методика физического воспитания / под редакцией Т. Ю. Круцевич. - Київ : Олимпийская литература, 2003. - Том 2. - 392 с.. 10. Царик А. В. О культуре физической и духовной / А. В. Царик // Физкультура и спорт. - 1989. - № 1. - С. 3-96.

УДК 51(07)

Сергій Семенець

\section{СИСТЕМОТВІРНЕ ПОНЯТТЯ ТА ОСОБЛИВОСТІ ЗМІСТУ РОЗВИВАЛЬНОГО НАВЧАННЯ МАТЕМАТИКИ}

Семенець С. П. Системотвірне поняття та особливості змісту розвивального навчання математики.

У роботі визначено системотвірне поняття, розкрито засадничі вимоги до змісту розвивального навчання математики, що забезпечують досягнення цілей особистісного розвитку суб’єктів навчально-математичної діяльності. За результатами змістово-теоретичного аналізу сформульовано основні концептуальні положення розвивального навчання математики.

Ключові слова: системотвірне поняття, математична модель, зміст навчання, розвивальне навчання математики.

Семенец С. П. Системообразующее понятие и особенности содержания развивающего обучения математике.

В работе определено системообразующее понятие, раскрыты основополагающие требования к содержанию развивающего обучения математике, обеспечивающие достижение целей личностного развития субъектов учебно-математической деятельности. По результатам содержательно-теоретического анализа сформулированы основные концептуальные положения развивающего обучения математике.

Ключевые слова: системообразующее понятие, математическая модель, содержание обучения, развивающее обучение математике.

Semenets S. P. System-concept and features of the developmental training content of Mathematics.

In the paper the concept of the term system-concept is defined, the basic requirements for the developmental training content of Mathematics, ensuring the achievement of the goals of personal development subjects of teaching and mathematical activity are represented. According to the results of the theoretical analysis the basic conceptual positions of the developmental training content of Mathematics are defined.

Key words: system-concept, a mathematical model, the content of training, developmental training of Mathematics. 